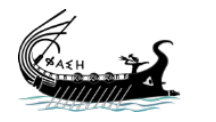

journal.phaselis.org

open?access journals
PHAS $<1<$ Disiplinlerarası Akdeniz Araştırmaları Dergisi

Journal of Interdisciplinary Mediterranean Studies

Volume II (2016)

\title{
Tavuk Adası Antik Rıhtım Alanı
}

\section{The Ancient Dock of Tavuk Adası}

\author{
Yusuf KILIÇ - Yasin GÖçER
}

PHASELIS: Disiplinlerarası Akdeniz Araştırmaları Dergisi'nde bulunan içeriklerin tümü kullanıcılara açık, serbestçe/ücretsiz "açık erişimli" bir dergidir. Kullanıcılar, yayıncıdan ve yazar(lar)dan izin almaksızın, dergideki makaleleri tam metin olarak okuyabilir, indirebilir, dağıtabilir, makalelerin çıktısını alabilir ve kaynak göstererek makalelere bağlantı verebilir.

PHASELIS: Disiplinlerarası Akdeniz Araştırmaları Dergisi uluslararası hakemli elektronik (online) bir dergi olup değerlendirme süreci biten makaleler derginin web sitesinde (journal.phaselis.org) yıl boyunca ilgili sayının içinde (Volume II: Ocak-Aralık 2016) yayımlanır. Aralık ayı sonunda ilgili yıla ait sayı tamamlanır.

Dergide yayımlanan eserlerin sorumluluğu yazarlarına aittir.

Atıf Düzeni Y. Kılıç - Y. Göçer, "Tavuk Adası Antik Rıhtım Alanı". Phaselis II (2016) 297-310.

DOI: 10.18367/Pha.16021

Geliş Tarihi: 20.10.2016 | Kabul Tarihi: 05.12.2016 | Online Yayın Tarihi: 31.12.2016

Editörya Phaselis Research Project

www.phaselis.org 


\title{
Tavuk Adası Antik Rıhtım Alanı
}

\section{The Ancient Dock of Tavuk Adası}

\author{
Yusuf KILIÇ* Yasin GÖÇER**
}

Öz: Günümüzde Balıkesir ili, Ayvalık ilçesi kıyı hattında yer alan Tavuk Adası üzerinde Hıristiyanlar için kutsal bir kişi olan Vaftizci Yahya'ya ait manastır bulunmaktadır. Kıyı hattına yakın olan adanın bir o kadar da anakaradan izole olması ve üzerinde bulunan tatlı su kaynağı burayı uygun bir yaşam alanı haline getirmiştir. Bölge antik yazarlar tarafından sık olarak ele alınmış olsa da, adanın ismi Doğu Roma'nın çöküşü ile birlikte (1453) Edremit Kadıköy'den gelen iki keşişin ada üzerinde ilk kiliseyi inşa etmeleriyle duyulmaya başlanmıştır. Buradaki yerleşimin başlangıcı ile birlikte ulaşım için muhtemelen rıhtım, iskele vb. bir yapıya ihtiyaç duyulmuştur. Kuzeyde yer alan modern iskelenin altında, manastır yapısı ile çağdaş ve bölgedeki yoğunluğu karşılayabilecek büyüklükteki taş rıhtım alanı çalışmamız kapsamında incelenmiştir. Bugüne kadar araştırılmamış olan antik taş rıhtımın, kara ve sualtı çalışmaları ile elde edilen verileri, ada üzerindeki manastır ile bağlantısı ve çevredeki rıhtım alanları ile benzerlikleri değerlendirilmiş, bu bağlamda antik taş rıhtımın inşasından günümüze kadar geçirdiği tarihsel süreç ortaya konulmak istenmiştir. Rıhtım alanı maruz kaldığı çevresel ve tektonik etkilerle yıpranarak sualtında kalmıştır ve alanda görülen değişim 19. yüzyıl sonlarından itibaren fotoğraflarla takip edilebilmektedir.

Anahtar Sözcükler: Ege · Ayvalık · Tavuk Adası · Antik Liman · Rıhtım

Abstract: Located by the coastline in the district of Balıkesir, Ayvalık, Tavuk Adası has a Monastery dedicated to John the Baptist, holy for Christians. Both because the island is close to the coastline but it is isolated from the mainland and is a place with freshwater sources it was a place suitable for human habitation. Although the region is frequently discussed by ancient writers, the island's name started to be recorded when the first church on the island, constructed by two monks from Edremit Kadikoy, with the the collapse of Byzantium (1453). Probably, it was required s structure such as a dock, pier etc. To service the transportation needs of the early settlement here. The stone dock area examined as part of our work, which is located under the north of the modern port is contemporary with the monastery, was large enough to service the requirements of the region.. This ancient stone dock which has not been studied to date, was researched both from the land and through underwater studies and its function was assessed in connection with the monastery on the island and its similarities with other dock areas in the region. This was put into historical context in respect to the construction of the ancient stone dock. The dock area has been exposed to environmental damage and erosion through being submerged, from tectonic activity and the changes to the area can be followed through photographs from the late 19th century onwards.

Keywords: Aegean · Ayvalık · Tavuk Adası · Ancient Port · Dock

* MA., Selçuk Üniversitesi, Edebiyat Fakültesi, Arkeoloji Bölümü, Konya. yusuffkilicc@gmail.com

** MA., Selçuk Üniversitesi, Edebiyat Fakültesi, Arkeoloji Bölümü, Konya. yasingocer1@ hotmail.com 
Üzerinde Hagios loannes Prodromos (Vaftizci Yahya) Manastırı bulunan Tavuk Adası ${ }^{1}$ Antikçağ Aeolis Bölgesi'nde, günümüzde ise Balıkesir ili, Ayvalık ilıçesi kıyı hattında yer alan irili ufaklı yirmi bir $^{2}$ adadan biri olup, Ali Bey (Cunda) Adası'nın yaklaşık 700 metre güneyinde, Ayvalık kıyı hattına yaklaşık 2800 metre mesafede, körfezin girişinde yer almaktadır ve sadece Dalyan Boğazı'nın dar geçidi ile açık denize bağlanan iç denizdeki tek adadır (Fig. 1). Ada yaklaşık 260 x 170 metre ölçülerinde ve doğu-batı doğrultusunda uzanmaktadır. Doğu yönünde en geniş kısmına ulaşan ada, yine bu yönde bir tepecik ile 7 metre yüksekliğe ulaşmakta, batı kısımda yaklaşık 46 metreye kadar daralmaktadır (Fig. 2). Hem anakaraya bu kadar yakın olması ile doğal gereksinimlerin kolaylıkla temin edilebilirliği, hem de anakaradan ayrı bir yerleşim oluşundan dolayı gürültü ve diğer dış etkilerden arınması, adanın yaşam alanı olarak tercih edilmesinde önemli rol oynamıştır. Ada üzerine Hıristiyanlar için kutsal öneme sahip bir kişilik olan "Vaftizci Yahya" adına bir manastır ${ }^{3}$ inşa edildiği ve inananların vaftiz için adada bulunan Ayazma'ya ${ }^{4}$ geldikleri bilinmektedir.

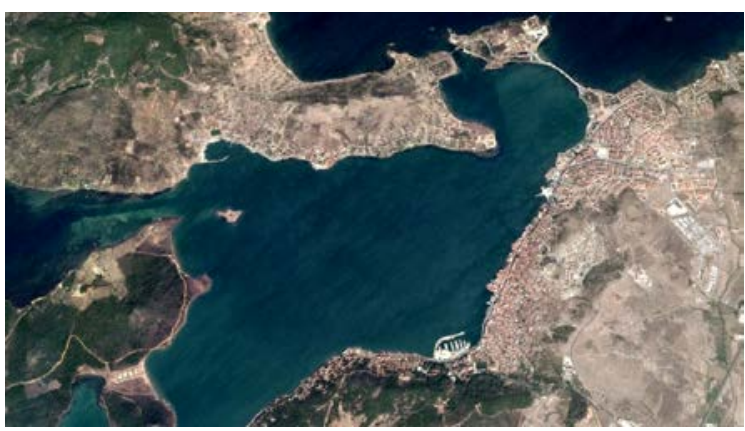

Fig. 1. Adanın Google Earth Görünümü

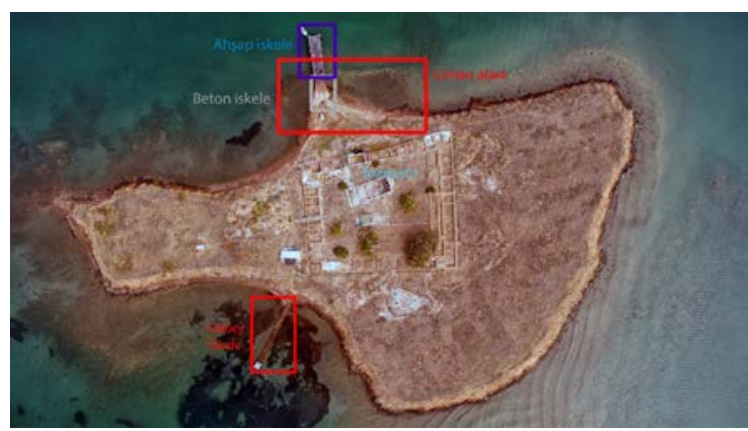

Fig. 2. Adaya Çıkış için Kullanılan Rıhtım ve Iskele Alanları

Literatür araştırmalarında, antik kaynaklarda bölge hakkında genel bilgi verildiği, özellikle Tavuk Adası'ndan bahsedilmediği görülmektedir. Bilimsel çalışmalar ise 2012 yılında yapılan kazı çalışması ${ }^{5}$ ile sınırlı kalmış, manastır odaklı yapılan bu çalışmalarda antik rıhtım alanında araştırma yapılmamıştır. Bu eksikliğin giderilmesi amacı ile yapılan çalışmamızda tarihi kaynaklar ve arkeolojik verilere dayanılarak limanın mimari değerlendirilmesi yapılmıştır.

\section{Tavuk Adasının Kısa Tarihi}

Antikçağdan günümüze kadar farklı siyasi ve etnik gruplara ev sahipliği yaptığı bilinen ve tüm tarihi boyunca Pagan, Hıristiyan ve Müslüman idareleri arasında sıkça el değiştiren Anadolu ve Ege Adaları'nda siyasi ve dinsel açıdan geçişler yaşanmıştır. Sonraki dönemlerde Rum Ortodoks Kilisesi'nin etkisi altında kaldığı bilinen bölge, Antikçağda Hellen kolonilerine dayandırılmakta, bu verilerden kullanım sürecinin antikiteden itibaren uzun bir tarih aralığına sahip olduğu anlaşımaktadır.

Antikçağda, "Hekatonnessos" olarak bilinen adalar grubundan, Plinius (nat. V. 39) 22 adadan

1 Balıkesir Ili'nin Ayvalık İlçesi'nde, Mithatpaşa Mahallesi, Tavuk Adası mevkii, 56 pafta, 1137 ada ve parsel 2'de yer almaktadır.

2 Bu adalardan yüz ölçümü olarak en büyük olan Cunda (Ali Bey) Adası'dır.

3 Tavuk Adası üzerinde yer alan Hagios loannes Prodromos (Vaftizci Yahya) Manastırı, yakın çevrede bulunan toplam 12 manastırın en eski tarihli olanıdır. Bk. Drakos 1895, 75-76.

4 Ortodoks Hıristiyanlarca kutsal sayılan kaynak veya pınarlara verilen isimdir. Ayrıca bk. Karaiskakis 1973, 131-136.

5 Tavuk Adası arkeolojik kazıları 4 Haziran-24 Eylül 2012 tarihleri arasında Balıkesir Arkeoloji Müzesi ile Eskidji A.Ş. şirketinin işbirliği ile adanın iyileştirilmesine yönelik yapılmıştır. 
oluştuğunu, Strabon (XIII. 2. 5), Timosthenes'in burada 40 adanın bulunduğundan bahsettiğini fakat 20 ada bulunduğunu aktarmaktadır. Bu adalardan en büyüğü günümüzde Cunda, Piri Reis'in Kitab-ı Bahriyesi'nde (Midilli Adası 291-325), Yund Adaları olarak adlandırılan Nasos/Ali Bey Adası'dır (Fig. 3). Texier Anadolu'ya yaptığı ilk seyahatinde bu bölgeden "birkaç ailenin barındığı bir harabe yığını" olarak bahsetmektedir". MS VI. yüzyılda korsan saldırılarından7 , MS VII. yüzyılda ise İslam donanmasının İstanbul'a ulaşmak için Akdeniz fetihlerine başlamasıyla, Haçlı, Venedik, Ceneviz, Türk, Karesi Beyliği arasındaki çatışmalarda yıkılıp yeniden iskân edilmiştir. MS X. yüzyılda Yunda Adası'nda yeniden küçük bir yerleşim kuruldu'. MS XIII. yüzyıl sonunda Ege Denizi'nde korsanların hâkimiyeti ve Ayvalık ve çevresindeki yerleşimlerin yeniden iskânı söz konusudur ${ }^{9}$. Kâtip Çelebi'nin Cihannüma adlı eserinde bahsettiği gibi Ayvalık çevresindeki ilk Türk yerleşimi 1462 Midilli Adası'nın Fatih Sultan Mehmet tarafından alınması ile paraleldir ${ }^{10}$.

1821 Ayvalık İsyanı'nda, bölgedeki diğer yapılar gibi zarar görmüş olan manastır, yaklaşık on yıl boyunca kullanılmamıştır. S. Karaiskakis, 1821 İsyanı sırasında Yunan donanmasının yenik düşen üyelerinin Tavuk Adası'ndaki manastırda toplandığından söz etmektedir ${ }^{11}$. Geçen bu zorlu süreç içerisinde birçok göç yaşanmış, Balkan Savaşları'nın ardından 1914 yllında tehcir ${ }^{12}, 1915$ yılında isyan ${ }^{13}, 1923$ yılında mübadele süreçleri ${ }^{14}$ devam etmiştir.

Yukarıda açıkladığımız bölge tarihine paralel olarak ada üzerindeki yerleşimi, yine bölge içinde önemli bir yeri olan manastır

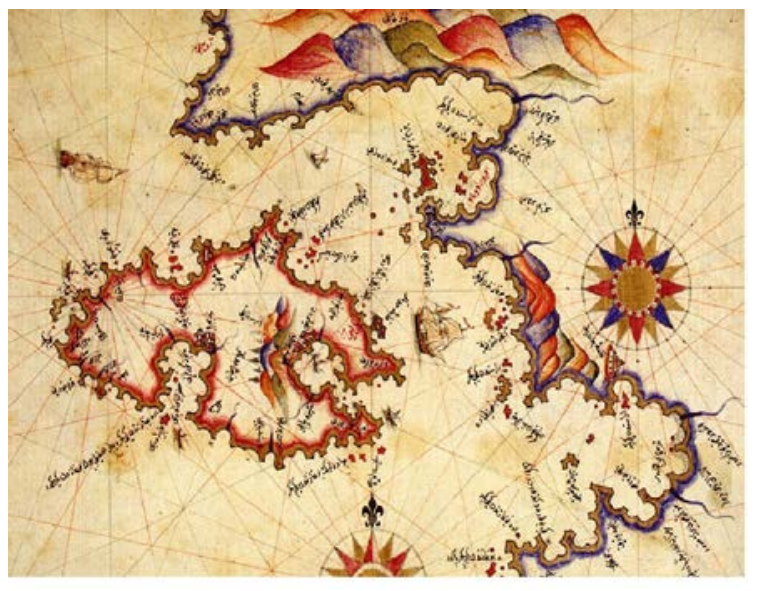

Fig. 3. Edremit Körfezi, Midilli ve Yund Adaları (Kitab-ı Bahriye) yapısı ile takip edilebilmektedir ${ }^{15}$. Kilisenin ilk kuruluşundan bir süre sonra Aynaroz'tan gelen keşişler, yapıyı bir manastır haline getirir ve böylece manastır Aynaroz'a bağlanmaktadır ${ }^{16}$. Kaynaklarda, 1677 'de manastırdan 'Monidrion'17, İncil'de yazdığı gibi (Markos İncil'i VI. 21-28) halk

6 Texier 1862, 207.

Kontis 1978, 86; Psarros 2004, 6-7.

Drakos 1888, 53.

9 Bu dönemde Ayvalık ve çevresindeki yerleşimler, Doğu Roma, Ceneviz, Venedik ve Türkler arasındaki çatışmalar nedeniyle yıkılıp yeniden iskân olunmuştur. Bk. Ruhyan - Lewis 1985, 38-40; Psarros 2004, 28 30.

10 Aka 1944, 18-9; Neşri 1984, 165; Uzunçarşılı 1998, 35-37; Kâtip Çelebi 70; konuya ilişkin olarak ayrıca bk. Balıkesir il Yıllığı 1973, 56.

11 Karaiskakis 1973, 130-136.

12 Bayraktar 2002, 36-38.

13 Bayraktar 2002, 39.

14 Soysal 1983, 177; Arı 1996, 498; 2000, 7.

15 Yazılı kaynaklardan elde edilen bilgiler ışığında yakın çevrede bulunanlar arasında en erken tarihli olan manastırın ilk yapımı, Doğu Roma çöküşü ile birlikte (1453) Edremit Kadıköy'den gelen iki keşişin ada üzerinde ilk kiliseyi inşa etmeleriyle başlamıştır. Günümüzden yaklaşık 550 yıl öncesine dayanan bu tarihten itibaren bütün yapım süreçleri tam olarak izlenememekle birlikte, 1677'de ilk başpapazın atanmasından sonra yazılı kayıtlar kesintisiz olarak devam etmektedir (Drakos 1895, 75-76).

16 Keşişler beraberlerinde getirdikleri bir Taksiyarhis ikonasını da kiliseye bağışlamıştır (Drakos 1895, 75).

171677 yılında manastıra atanan ilk başpapaz Neofitos Dönemi'nde, manastır şimdiki halinden daha küçük 
arasında Hagia Kara ${ }^{18}$, 1769- 73 yılları arasında ise 'stavropigiakimoni' olarak anılmaktadır ${ }^{19}$. 1774 yılında Moskonisya Episkoposluğu'na ${ }^{20}$ bağlanmaktadır.

Manastırın kilisesinde Ioannes Prodromos ve Taksiyarhis ikonalarının yanı sıra; çok büyük boyda bir Theotokhos Meryem ikonası ve çoğu 18. yüzyıla ait başka ikonalar da mevcuttur. íki rölik kutusu içinde: Ioannes Hrisostomas, Hagios Prokopis, Grigorios Thelogos, Aziz Elefterios, Aziz Trifon, Aziz Krikos, Aziz Kiprianos ve Kırk Azizlere ait rölikler bulunmaktadır. Bütün rölikler, 1817 'ten önce gümüşle kaplanmıştır ${ }^{21}$. Kilisenin içinde Ipsara Adası'ndan getirilmiş bir diskopotiron $^{22}$ da bulunmaktaydı. 1854 'de İzmirli Paisios tarafından yapılan sayımda, röliklerin yalnızca bir kutu kaldığı belirtilmektedir ${ }^{23}$. Bu bilgi, 1821 İsyanı'ndan 1832'deki af fermanına kadar geçen dönemde bazı kayıplar olduğuna işaret etmektedir.

Drakos, rıhtım alanına açılan taş malzemeli merdivenin bir papaz tarafından keyfi bir şekilde yıktırıldığını belirtmektedir ${ }^{24} .1826$ yılında ise başpapaz tarafından komple bir onarım söz konusu ${ }^{25}$, bu yüzden Drakos Kirillas Gudohiras'tan övgüyle söz etmektedir ${ }^{26}$.

Evstratios Drakos, kitabında ada ve ada üzerindeki manastır için, kutsal günlerde ${ }^{27}$ ve büyük panayırlarda ${ }^{28}$, yaklaşık 10.000 kişinin adada şenlik havasında toplandığı, çok sayıda gemi ve sandalın yanaştığı, misafirlerin konakladığı 128 hücresinin bulunduğu, önce 72 daha sonra 100 ciltlik bir kütüphaneye sahip olduğu, 1821 Yunan İhtilaline kadar bütün birimlerin 2 katlı olduğu, üst katların ahşap revaklar ile çevrildiği ve buna benzer birçok somut betimlemeler ile yapılan ifade geçmektedir ${ }^{29}$.

olduğundan dolayı yazışmalarda yapıdan 'Monidrion' (Küçük Manastır) olarak bahsedilir (Drakos 1895, 76).

18 Roma'nın Galilee ve Perea valisi Herodes Antipatros kardeşinin eşi Herodias ile evlenir. Onu uyaran Vaftizci Yahya'yı önce hapseder. Doğum gününde onun için dans eden Salome ve annesi Herodias'ın isteği üzerine, zindanda başını vurdurmuş ve bir tepsi içinde onlara sunmuştur. İnançsızlar tarafından şehit edilen Vaftizci Yahya'nın başı 'Hagia Kara' olarak anılmaktadır. Ayrıca bk. Cömert 2006, 175-176.

19 Bu tarihler aralığında İstanbul Patriği olan II. Theodosius tarafından manastıra 'stavropigiakimoni' (İstanbul Patrikhanesi'ne bağlı manastır) unvanı verilir (Drakos 1895, 77).

201774 yılında Patrik I. Samuel tarafından hazırlanan bir belge ile manastır, İzmir Metropolitliği'ne bağlı olan Moskonisya Episkoposluğu'na bağlanır ve 1922 yılına kadar öyle kalır (Karaiskakis 1973, 134-135).

21 Drakos 1895, 78.

22 Kadeh ve tepsiden oluşan bu rölik, kilisedeki komünyon ayinlerinde kullanılır.

23 Drakos 1895, 78.

24 Manastırda görev alan papazlara ait bilgiler incelendiğinde bu olay, muhtemelen, 1762-1774 arasında meydana gelmiş olmalıdır. Görev alan diğer başpapazlar manastıra yaptıkları katkılar, inşa faaliyetleri ile anılırken; 'keyfi tutumu' ve 'manastırı viraneye çevirmesi' nedeniyle Patrikhane tarafından azledilen tek başpapaz bu dönemde görev yapmıştır. Ayrıca bk. Drakos 1895, 76; Karaiskakis 1973, 134-135.

251826 yılında atanan başpapaz Kirillas Gudohiras, "1830 yılında kiliseyi çok kötü bir durumda devralmış", 1838'e kadar ada halkının da yardımları ile kiliseyi içten ve dıştan onartmıştır. Ayrıca bk. Karaiskakis 1973, 134-135.

26 Drakos da eserinde ondan "en yenilikçi yapımcı" olarak söz etmektedir (Drakos 1895, 79).

27 Ioannes Prodromos'un ölüm yıldönümü olan 29 Ağustos'ta başlayan büyük panayıra Ali Bey Adası, Ayvalık, Küçükköy, Edremit, Dikili ve Bergama gibi yerleşimlerden sandallarla gelen halk burada büyük bir deniz trafiği oluşturuyordu (Drakos 1895, 79).

28 Manastırdaki ikinci büyük panayır, 14 Eylül'deki Timi Stavro Günü (Kutsal Haç Yortusu) idi. Her yıl bu tarihte Balya'dan gelen Pontuslu Madenciler, manastırın misafirhanesinde kalıyordu. Halk, Büyük Perhizin ilk günü olan Kathara Defthera (Temiz Pazartesi) ve Paskalya'dan sonraki ilk pazartesi Lambro Defthera (Aydınlık Pazartesi) günü de, loannes Prodromos Manastırı'nda toplanarak şenlikler yapılmaktaydı (Tsernoglou 1988, 15).

29 Drakos 1895, 76. 
Ada'da yaşam manastırın yıkımından sonra tamamen sona ermiştir ve manastır günümüzdeki görünümüne 19. yüzyılın sonunda kavuşmuştur ${ }^{30} .4$ Haziran - 24 Eylül 2012 tarihleri arasında, Balıkesir Müze Müdürlüğü başkanlığında sadece manastırın yer aldığı arsa üzerinde, "manastırın temel izlerinin araştırılmasına yönelik kazı" çalışmaları yürütülmüş ve bu çalışmalar tamamlanmıştır. Kazı sonrasında manastırın temel izlerinin tamamına yakını ortaya çıkarılmıştır. Yapının \%90'a yakın kısmı tamamen yok olmakla birlikte, plan şemasını izleyebilecek düzeyde temel ve duvar izleri tespit edilmiştir. Yapının günümüze ulaşan en sağlam kısmı, kilisenin apsis duvarı ve kısmen kuzey ve güney duvarlarıdır.

\section{Tavuk Adası Kuzey Rıhtım Alanı}

Günümüzde Tavuk Adası üzerine ulaşımın sağlanması için biri kuzey diğeri güney yönünde olmak üzere iki adet rıhtım bulunmaktadır ${ }^{31}$ (Fig. 2). Kuzeyde modern iskelenin altında manastır yapısı ile çağdaş ve bölgedeki yoğunluğu karşılayabilecek büyüklükte olduğu düşünülen taş rıhtım alanı bulunmaktadır ${ }^{32}$.

Rıhtım alanı, adanın kuzey kıyısında yaklaşık 1700 metre karelik bir alanı kapsamakta ${ }^{33}$ ve $7 \mathrm{x}$ 3 m ölçülerindeki taş döşeli bir yol ile manastır kompleksine bağlanmaktadır. Bu sayede adanın dışarıya açılan kapısı olarak tasvir edilebilmektedir. Taş rıhtıma ait sarımsak taşından ${ }^{34}$ oluşturulan bloklar yaklaşık $65 \mathrm{~m}$ uzunluğunda $25 \mathrm{~m}$ eninde bir alana dağılmış halde ve neredeyse tamamı sualtında bulunmaktadır ${ }^{35}$ (Fig. 4- 6, 10). Dörtgen form göstermeyen bloklar kullanılarak iki sıra halinde örülen duvarlarda ince işçilik görülmemektedir.

Doğudan başlayarak modern ahşap iskeleye kadar aynı açıyla devam eden antik taş rıhtım duvarı, ahşap iskelenin altından başladığı görülen bir kırılma ile 40 derece güneye dönerek 16,70 $\mathrm{m}$ batıya doğru devam etmektedir. Burada doğu duvarından farklı olarak batı duvarın kıyıya, önce 80 derecelik açıyla doğuya, 3,30 m devam ettikten sonra 85 derecelik açılla güneye doğru uzanmakta, bu noktadan kıyıya uzandığı anlaşılan duvarın ölçülebilen uzunluğu 7,70 metredir. Buradaki farklı düzenleme "L" biçiminde bir plan ortaya çıkarmaktadır (Fig. 7, 10). Bu düzenlemenin işlevi araştırıldığında, Vitruvius'un (de Arch. V, XII) da eserinde bahsettiği gibi

30 Başpapaz Akakios 1870-1878 yılları arasında, manastırın büyük bölümünü yenilemiş ve ilaveler yapmıştır. Bu inşa faaliyetlerine olasılıkla 11 Nisan 1867 Ayvalık, 14 Temmuz 1870 Balıkesir - Çanakkale Depremleri neden olmuştur. Konuya ilişkin olarak ayrıca bk. Pınar - Lahn 1952, 30-59; Soysal 1981, 31-64; Yazıcı 2003, 9-10.

31 Güney de bulunan rıhtım, Çamlık ve Küçük köy hattından gelenler tarafından kullanılırken, kuzey yönünde Cunda ve çevredeki yerleşimlerden gelenler için daha büyük bir rıhtım bulunmaktadır.

32 Ada üzerindeki Hagios loannes Prodromos Manastırı́na, inananların vaftiz ve çeşitli kutsal şenlikler için teknelerle gelmesiyle adanın bölge içerisinde ön plana çıkması adaya büyük bir rıhtım alanını zorunlu kılmıştır (Drakos 1895, 79).

33 Adanın doğu ucundan yaklaşık 100 m batıdan başlamakta ve hazırlanan karelajda 2C-C3, 1C-A1 noktaları arasında bulunmaktadır.

34 Lav birikintileriyle oluşan, kolay şekil alan; ancak son derece sağlam olan bu taşlar, bölgedeki evlerin yapımında temel malzeme olarak kullanılmıştır. Aynı zamanda yoğun olarak çıkarıldığı Ayvalık'ın Küçükköy Beldesine de kendi adını vermiştir. Yöreden çıktığı için coğrafyaya uyumuyla iklimlendirmede de yapılara işlevsellik katan ve ünü Osmanlı Dönemi'nde artan sarımsak taşı, Balkanlar'dan Ortadoğu'ya kadar pek çok cami ve kilisede kullanımıştır.

35 Alanda yapılan belgeleme çalışmaları ile rıhtım alanını oluşturan duvar bloklarının mevcut durumu tespit edilmiştir. Ayrıntılı bir duvar iş̧̧iliği görülmeyen iskele duvarı, dörtgen form göstermeyen sarımsak taşından bloklar kullanılarak iki sıra halinde örülmüştür. Elde edilen verilerden anlaşıldığı üzere rıhtım alanı; doğuda 0,90 x 16,80 m ölçülerinde kıyıdan kuzeye doğru uzanmakta, buradan yaklaşık 80 derecelik bir açıyla batı yönüne dönüş yapmaktadır. 0,90 m kalınlığında büyük oranda tahrip olmuş olan duvar $36 \mathrm{~m}$ boyunca batıdaki modern iskeleye kadar takip edilebilmektedir. 


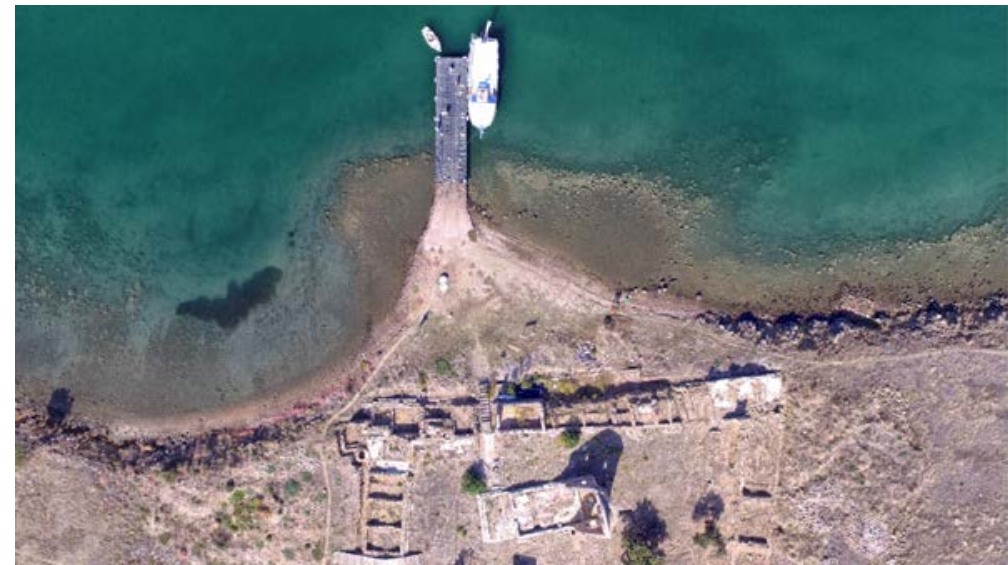

Fig. 4. Rıhtıma Ait Blokların Alana Dağılımı

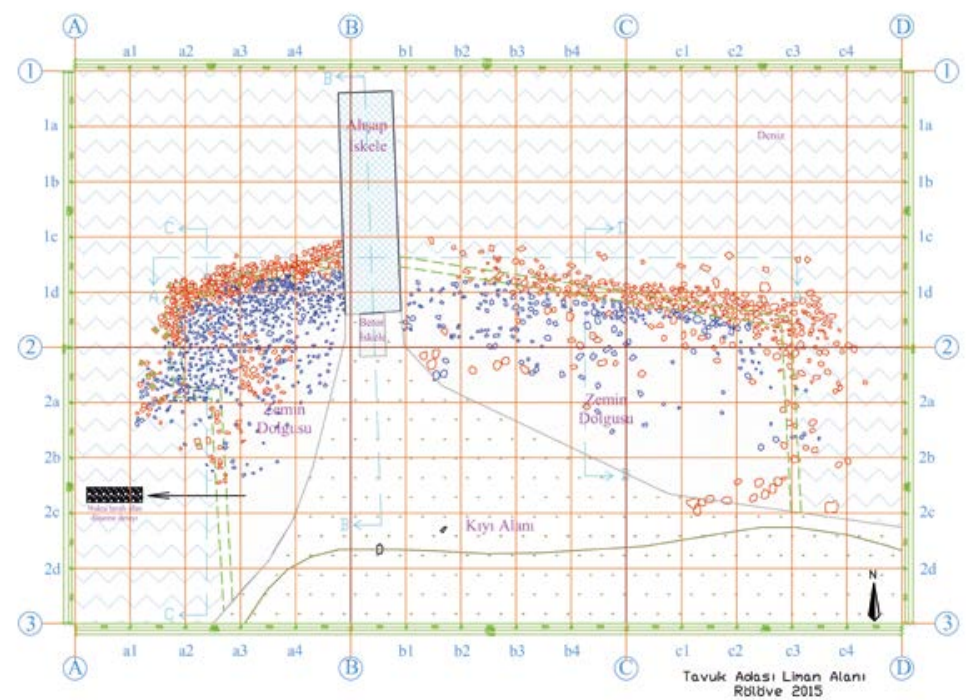

Fig. 5. Rıhtım Alanı Rölöve Çizimi

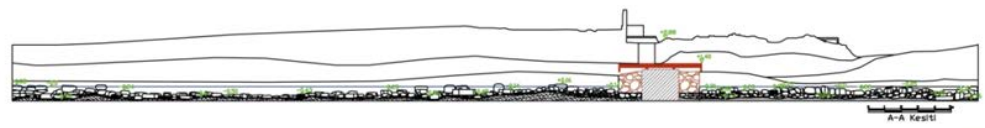

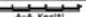

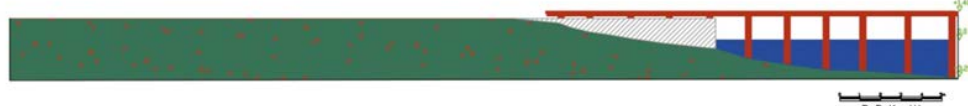

$\underset{\mathrm{B}-\mathrm{B} \text { kessiti }}{\min }$
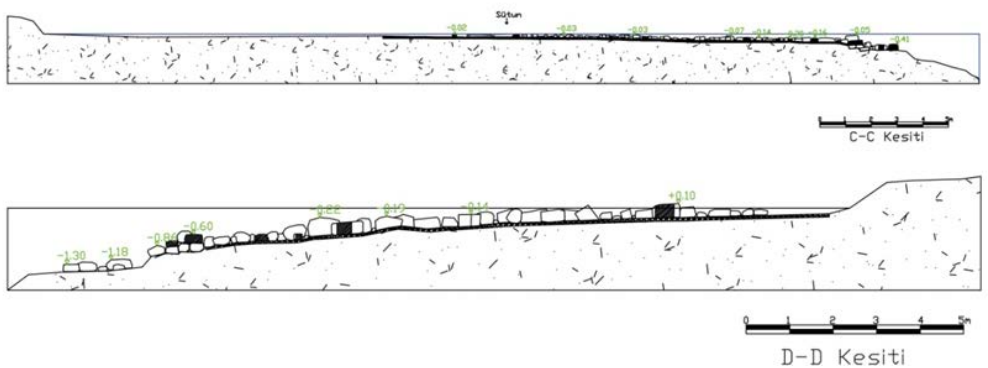

Fig. 6. Taş Rıhtım Alanı A-A, B-B, C-C, D-D Kesitleri 


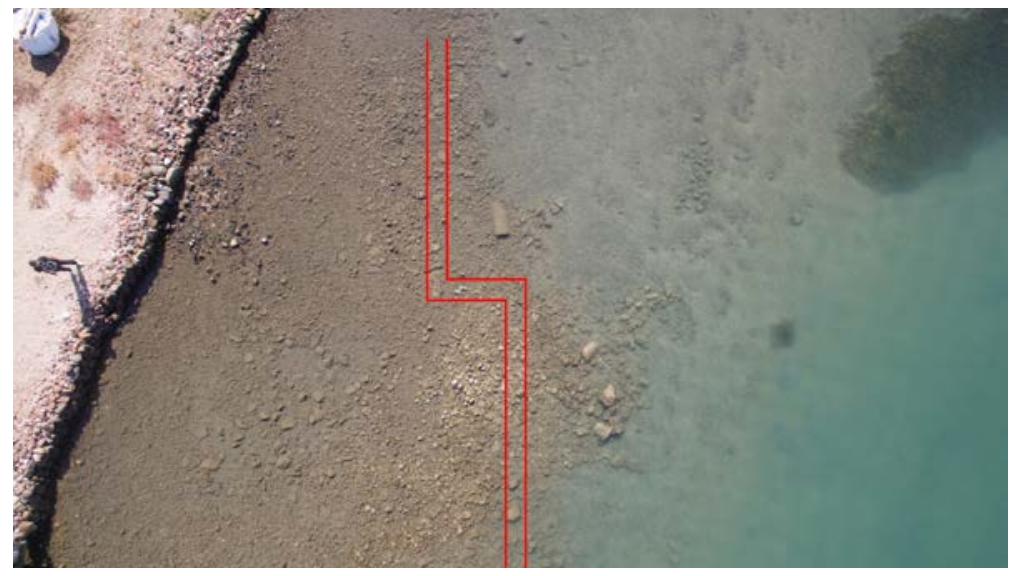

Fig. 7. Batı Kısımda Bulunan "L" Biçimli Duvar

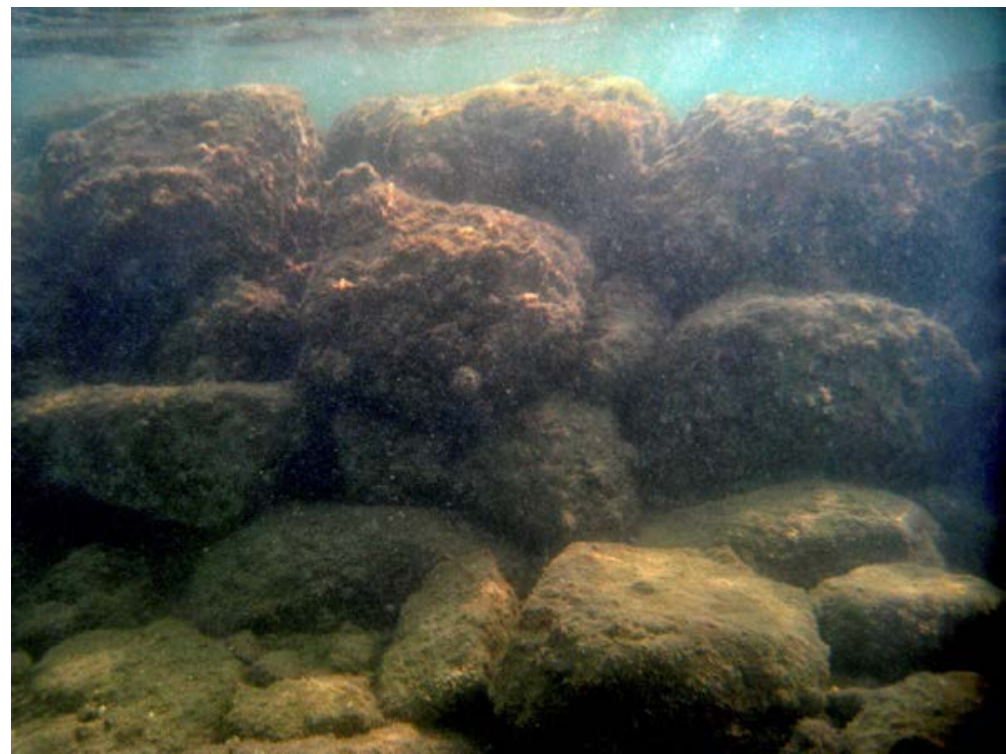

Fig. 8. Duvarın En Iyi Korunan Kısmının Sualtından Görünümü

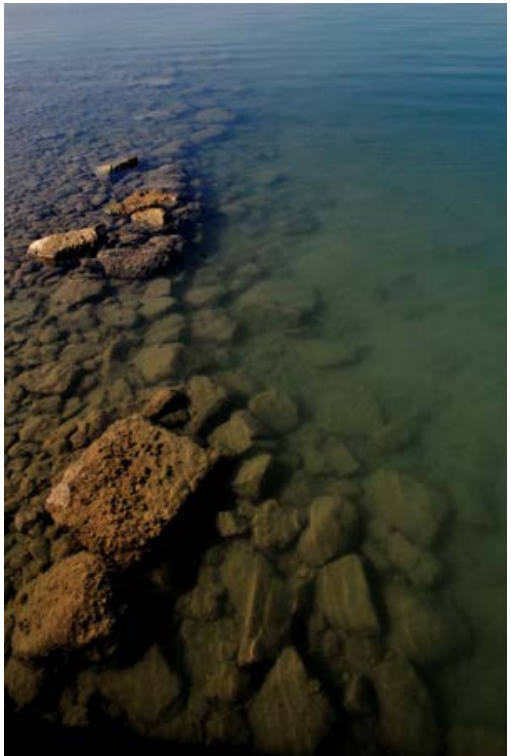

Fig. 9. Duvara Ait In Situ Blokların Genel Görünümü 

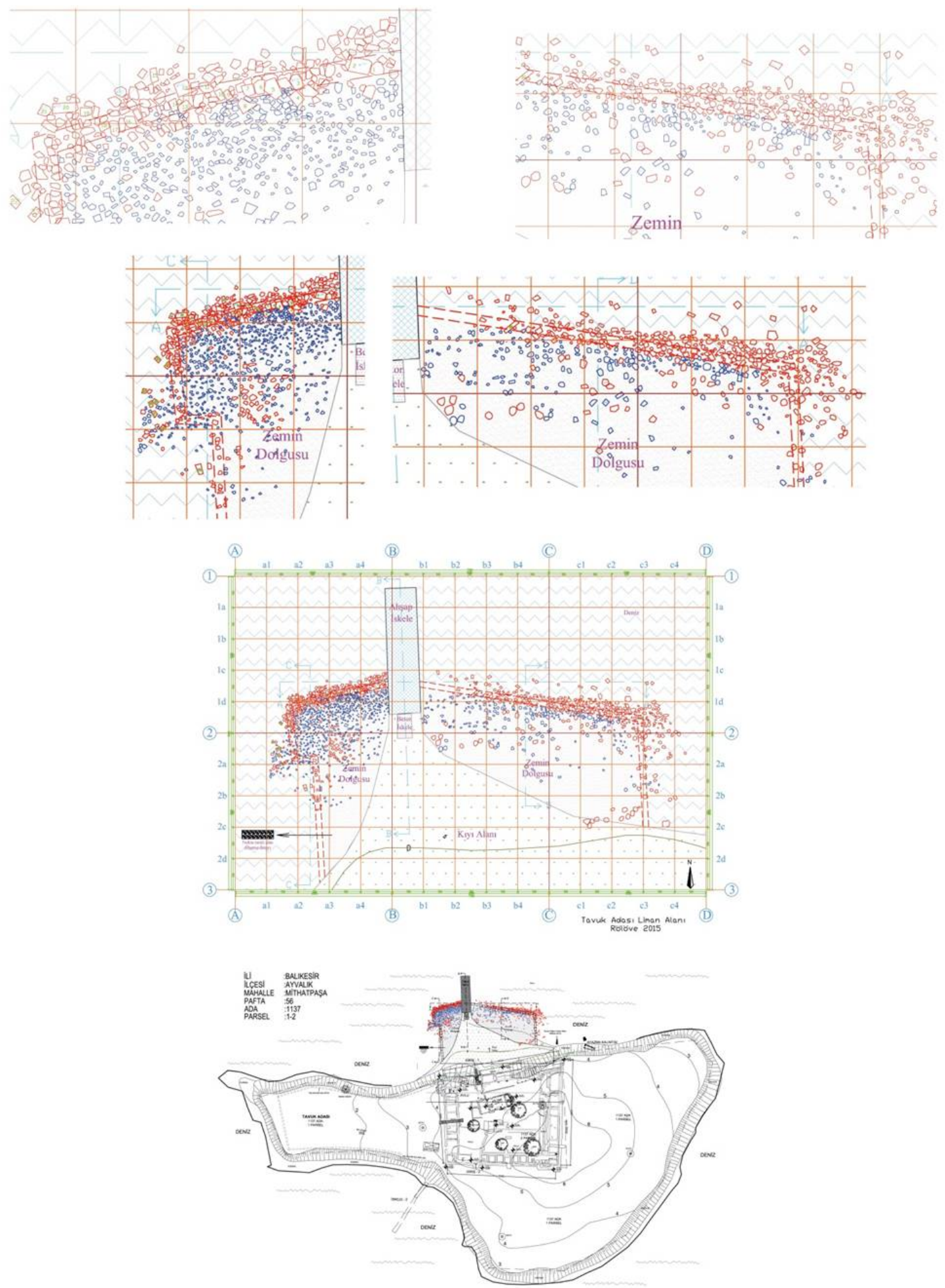

Fig. 10. Adanın ve Rıhtım Alanının Rölöve Çizimi 
hâkim rüzgarların yönü ve şiddeti dikkate alınarak koruma amaçlı yapılmış olduğu anlaşılmaktadır ${ }^{36}$. Kekova Adası Kuzey Yerleşim Alanı'nda rastladığımız benzer uygulama ${ }^{37}$, çevredeki rıhtım alanlarında görülmemektedir. Fakat çevredeki rıhtım alanlarının yönleri belirlenirken, buradaki gibi rüzgârın dikkate alındığı net olarak anlaşılmaktadır ${ }^{38}$.

Büyük bir kısmı tahrip olan rıhtım duvarın en iyi korunan kısmı kuzey yönde modern rıhtımdan 4,90 m batıda bulunmakta, üst üste üç sırası görülebilen ve 1,45 $\mathrm{m}$ boyunca devam eden duvarın ölçülebilen yüksekliği 0,65 metredir (Fig. 6 AA kesiti, 8-9). Rıhtımın 0,70 m batısından başlayarak $10 \times 0,90 \mathrm{~m}$ batı doğrultusunda uzanan alanda duvar hattının algılanmasını sağlayan ve hazırlanan plan üzerinde $1,2,3,5,6,7,9,10,13,14,16,17,18$ numaraları ile gösterilen toplamda 13 adet in situ blok bulunmaktadır (Fig. 9, 10). Rıhtım bloklarının en derinde olanı sualtında -1,30 metrede iken çoğunluğu 0,0/-0,50 m aralığında bulunmaktadır (Fig. 6). Bloklar arasında kayıt altına alınan 30 adet blok haricinde büyük bir kısmı gerek dalga ve akıntıların zamanla aşındırması gerekse yosun ve kekamoz tabakasının üzerlerini kaplamış olması nedeniyle blokların sınıflandırılması için net bir ölçü vermemekte ve blokların üzerinde herhangi bir silme, kenet ya da dübel izi olup olmadığı görülememektedir.

Doğu, batı ve kuzey yönlerine duvar örülmesiyle yaklaşık 1000 metre karelik kapalı bir alan elde edilmiş ve alanın içerisi dolgu malzemesi ile doldurularak üzerine yaklaşık 0,05-0,10 m aralığında boyutlara sahip yuvarlak taşların dizilmesiyle bir taban döşemesi oluşturulmuştur. İskelenin batısında kalan yaklaşık 300 metrekarelik alanda taş döşeme yoğun olarak görülürken doğu kısımda daha seyrek olarak takip edilebilmektedir (Fig. 5, 10). Gerek manastırın ve manastır kompleksini oluşturan odaların zemininde, gerekse manastıra giriş çıkışı sağlayan ve ölçülebilen uzunluğu 7 m olan -olasılıkla rıhtım alanı içerisine kadar devam eden- taş döşemeli yoldaki taş iş̧̧iliği, rıhtım alanındaki zemin döşemesi ile karşılaştırıldığında malzeme ve işçilik açısından aynı özellikler göstermekte, olasııkla eş zamanlı yapılmış olmalıdır.

Alan içerisinde rıhtımı oluşturan bloklara ek olarak yine batı kııımda kıyıdan 18 m kuzeyde 0,55 x 0,95 m ölçülerinde bir adet, kıyıdan $31 \mathrm{~m}$ kuzeyde, ahşap iskeleden 14,30 m batıda bir adet olmak üzere toplam 2 adet sütun parçası bulunmaktadır (Fig. 11). Rıhtım alanına ait 0,40 $x$ 0,60 × 0,34 m ölçülerindeki diğer bir blok ise kıyıdan 26 m kuzeyde, ahşap iskeleden ise 15,90 m batıda bulunmaktadır. Rıhtım alanına yanaşan teknelerin bağlanmasında kullanılan bu bloğun ortasında 0,16 m çapında bağlama deliği bulunmakta ve palamar bağlama halkası olarak bilinmektedir $^{39}$ (Fig. 11-12).

\section{Değerlendirme ve Öneriler}

Günümüzdeki durumuna bakıldığında 60 × 30 m bir alana dağılmış durumda olan taş rıhtım, ada üzerindeki manastır yapısına kısmen paralel olarak uzanmaktadır. Manastır avlusuna girişi sağla-

36 Nitekim bölgedeki rüzgârlar incelendiğinde kuzeydoğudan -Edremit Kaz Dağları üzerinden- esen poyraz özellikle kış aylarında büyük dalgalara neden olmaktadır. İskele alanında bu doğal faktörlerin etkisi azaltılmak için doğu kısmı batı kısma göre daha dar tutulmuş ve duvar en kısa mesafede kıyı ile birleştirilmiştir. Olasılıkla sert rüzgârlardan korunmak için rıhtım alanının batı yönünde oluşturulan "L" biçimindeki korunaklı alana tekneler yanaşmaktadır.

37 Aslan 2011, 73, 74.

38 İskele alanının 740 m batısında Kumru Koyu'nun kuzeyinde kalan yarımadanın kuzey ucunda $25 \times 40$ m ölçülerinde aynı yöne ve neredeyse aynı açıyla inşa edilmiş bir iskele alanı görülmektedir.

39 Palamar bağlama halkası olarak bilinen taş halka aslında 'mooring stone' olarak adlandırımaktadır. Konuya ilişkin olarak ayrıca bk. Testaguzza 1964, 173; Blackman 1973, 355; Williams 1976, 73; Blackman 1982, 203; Theodoulou - Memos 2007, 253; Aslan 2013, 29. 
yan kuzeydeki taş döşemeli yol tam olarak taş rıhtımın bulunduğu alana bakmaktadır. Rıhtım alanının genel mimarisine bakıldığında, çerçeve oluşturacak şekilde alanı sınırlayan duvar hattı ve bu hattın sınırladığı alanın dolgu malzemesi ile doldurulmasıyla rıhtım alanının oluşturulduğu görülmektedir. İskelenin sarımsak taşı bloklarla inşa edilen duvarının bir kısmı günümüze in-situ vaziyette ulaşırken, iç kısımda küçük moloz taşlarla oluşturulan zemin döşemesinin bir bölümü sağlam kalmayı başarmıştır. Bu veriler doğrultusunda taş rıhtımın inşa tekniği ve planlaması net olarak anlaşılabilmekte ancak tarihlendirilmesi noktasında kesin bir sonuca ulaşılamamaktadır.

Kuşkusuz bu alana yapılan rıhtım, ada üzerinde yer alan ve ilk evresi MS 1453 yılından hemen sonraki tarihlere verilen manastır ile çağdaştır, ancak manastırın ilk inşa edildiği dönemden günümüze kadar çok sayıda onarım ve inşa evresi geçirmiş olduğu bilinmektedir ${ }^{40}$. Dolayısıyla ilk inşa edilen rıhtımın boyutu ve planı günümüze ulaşan kalıntılar ile benzeşip benzeşmediği bilinmemektedir. Günümüze ulaşan ve halen sualtında bulunan antik taş rıhtımın kuzey duvarı batı uçtan başlayarak doğu yönüne $16 \mathrm{~m}$ devam ettikten sonra yaklaşık 40 derecelik bir açı ile güneye doğru eğim yapmakta ve buradan da $36 \mathrm{~m}$ daha devam ederek 90 derecelik bir dönüşle adaya bağlanmaktadır. Diğer yandan rıhtımın batı ucunda $9 \mathrm{~m}$ güneye, ardından $3 \mathrm{~m}$ doğu ve tekrar $8 \mathrm{~m}$ güneye uzanarak adaya birleşen duvar " $\mathrm{L}$ " biçiminde bir form oluşturmakta ve bu düzenleme rıhtımın doğu ucunda görülmemektedir. İskelenin doğu ve batı uçlarındaki bu farklııklarının yanı sıra çerçeve duvarında kullanılan bloklarda da nitelik ve taş cinsi bakımından farklılıklar gözlemlenebilmektedir. Öyle ki batı bölümde yer alan bloklar doğu bölümde bulunanlardan daha düzgün kesilmiştir ve aralarında sarımsak taşı bloklarda yer almaktadır. Doğu bölümdeki bloklar incelendiğinde ise adanın doğu kıyılarındaki kayalık alana benzer renkte daha özensiz bloklardan inşa edildiği gözlemlenmektedir. Dolayısıyla manastırın farklı dönemlerde geçirdiği onarım faaliyetlerinin rıhtım alanını da kapsadığı yorumu çıkarılabilmektedir. Olasıııkla başlarda daha mütevazı bir rıhtımın yer aldığı bu alana sonraki dönemlerde ihtiyaca yönelik olarak daha büyük bir rıhtım ve gerisindeki platform oluşturulmuştur ${ }^{41}$.

Kutsal gün ve düzenlenen büyük panayırlar için gelenlerin tekne ve sandalları ile yanaşarak adaya çıkması için kullanıldığı anlaşılan taş rıhtım alanının işlevini, günümüzde üzerine inşa edilen beton ve devamındaki modern ahşap iskele sürdürmektedir (Fig. 2). Orijinal taş rıhtımın ne zaman ve hangi sebeple sualtında kaldığı sorusu ise tam olarak cevaplanamamakla birlikte eldeki veriler ve yakın zamana ait belgelerle kısmen açıklanabilmektedir. Buna yönelik ilk veri, taş rıhtımın nispeten daha iyi korunmuş olan batı bölümündeki zemin döşemesidir. Yuvarlak taşlar kullanılarak oluşturulan zemin döşemesi hem manastırın avlusunda, hem de manastır ile rıhtım alanı arasındaki rampalı yolda kullanılan döşeme ile bütünlük oluşturmaktadır. Her iki alanda görülen uygulamanın bir bütün oluşturacak kadar sağlam kalmış olması, bu alanın tek seferde sualtında kaldığını sonradan sökülerek derinleştirilmediğini göstermektedir. Çevre duvarının ise bu alana

40 Doğu Roma'nın çöküşü ile (1453) Edremit Kadıköy'den gelen iki keşiş, ada üzerinde ilk kiliseyi inşa etmişlerdir. Sonrasında küçük kilise Aynaroz'dan gelen keşişler tarafından manastır haline getirilmiş ve manastır Aynaroz'a bağlanmıştır. 1677'de ilk başpapazın atandığı ve 18. yüzyılda çift kollu taş merdivenin yıkılması ile 1762-74 yılları arasında onarım geçirdiği bilinmektedir. 1806 tarihli mermer kitabede yeni yapımdan bahsedilen manastır yapısı 1821 isyanından sonra 1830'da tekrar onarım görmüştür. Son olarak, 1867 ve 1870 depremleri sonrasında 1878'de aynı temeller üzerinde yeniden yapımı söz konusudur. Ayrıca bk. Drakos 1895, 75-76.

41 Halk yaz mevsiminde ve pazar günleri ve kışın güneşli havalarda bu manastıra sandallarla geliyordu. loannes Prodromos'un ölüm yıldönümü olan 29 Ağustos'ta ada üzerinde büyük panayırların düzenlendiği ve Ali Bey Adası, Ayvalık, Küçükköy, Edremit, Dikili ve Bergama gibi yerleşimlerden gelen cemaatin burada toplandığı bilinmektedir (Drakos 1895, 79). 


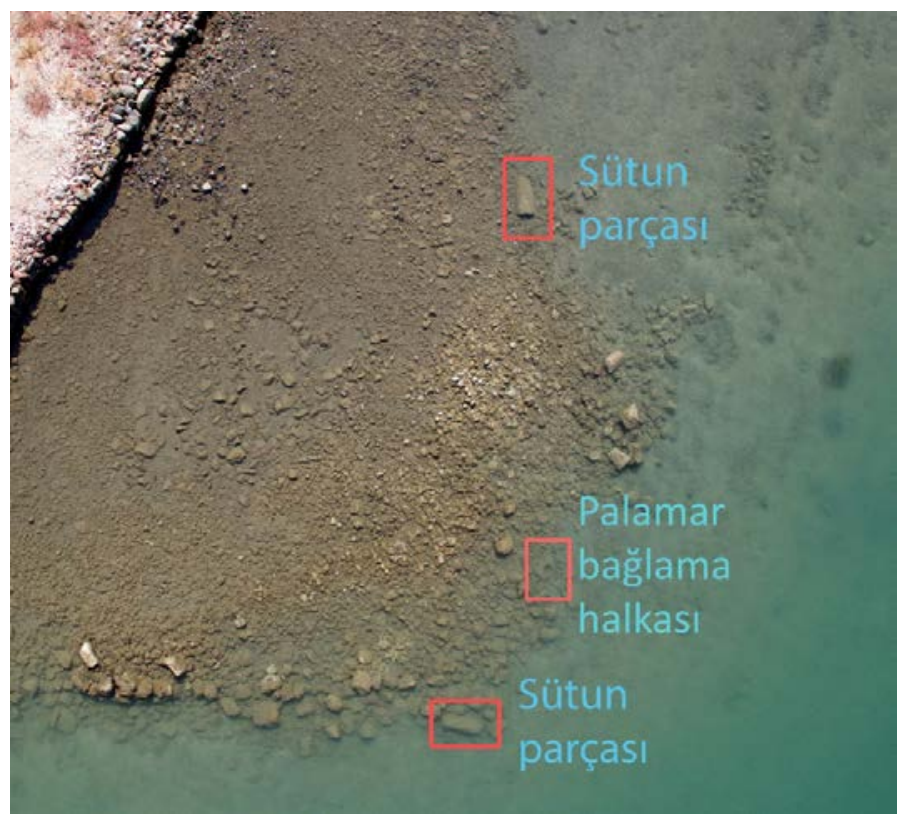

Fig. 11. Taş Rıhtım Alanı Batı Kısımda Yer Alan Buluntular

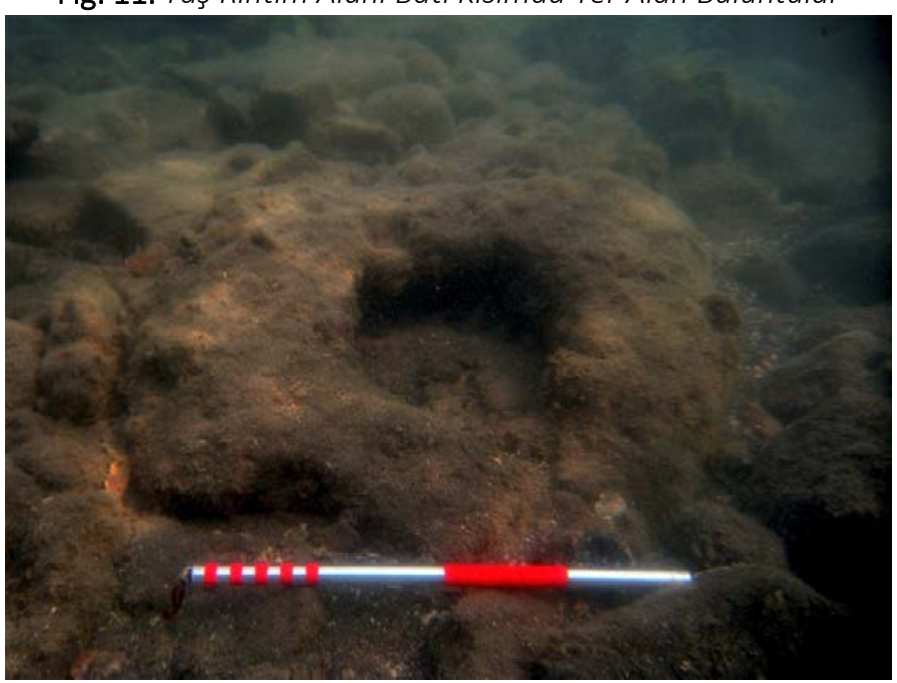

Fig. 12. Palamar Bağlama Halkası Sualtı Görüntüsü

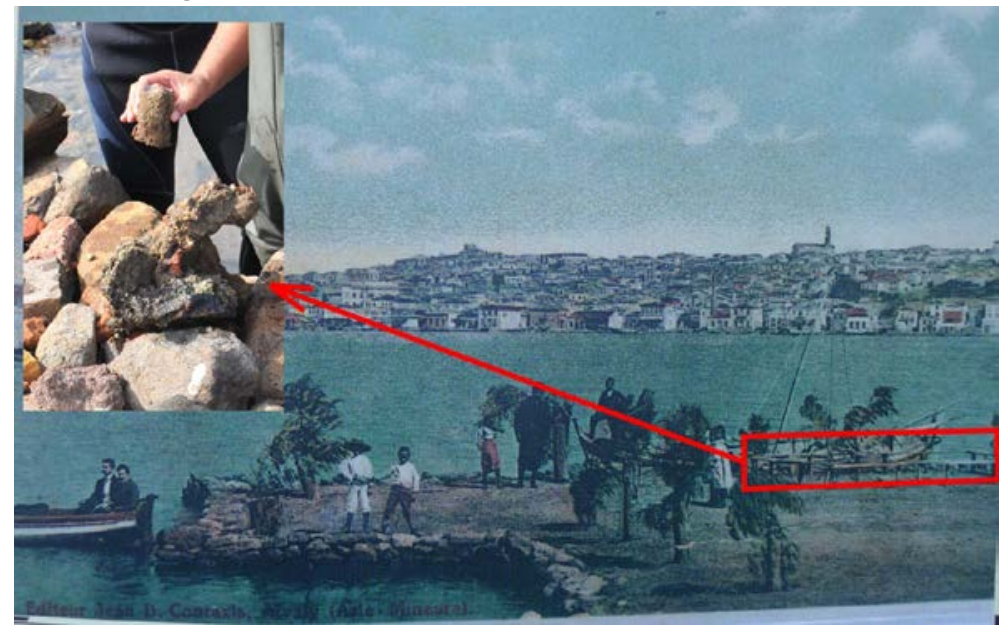

Fig. 13. Taş Rıhtımın 1880 Yılında Çekilen Bir Fotoğrafı (Mimar Müjdat Soylu) 
sonradan yapılan ve günümüzde de kullanılan beton rıhtım için söküldüğü anlaşılmaktadır. Taş rıhtımın, 1880 yılında çekilen, rıhtımın bir bölümünün görüldüğü fotoğrafta, sağlam ve deniz seviyesinin oldukça üzerinde olduğu görülmektedir (Fig. 13). 1949 yllında çekilen bir sonraki fotoğraf ise 1973 yılında burada çekilen bir Türk filmindeki ${ }^{42}$ iskeleye benzemektedir. Fotoğraflardan da anlaşıldığı kadarıyla orijinal rıhtım 1880 ile 1949 yılları arasındaki bir tarihte sualtında kalmış olmalıdır. Bu iki tarih arasında bölgedeki kıyı şekillerini değiştirebilecek ölçüde AyvalıkBalıkesir depremi adı verilen bir deprem söz konusu olmuştur. Deprem 06.10.1944 tarihinde saat 04.30'da Ayvalık'ta ve 6,8 şiddetinde gerçekleşmiş ${ }^{43}$, Ayvalık tarihindeki en büyük depremlerden biri olmuştur. Toplam 30 kişinin öldüğü ve yaklaşık 5.500 binanın hasar gördüğü depremin Cunda (Ali Bey) Adası'nda da büyük hasara neden olduğu, hatta kıyısında tsunami oluştuğu bilinmektedir. Nitekim o dönem ada halkından biri olan Ali Onay'ın anlatımı depremin etkisini gözler önüne sermektedir ${ }^{44}$. Yapılan araştırmalar ışığında adanın birinci derece deprem bölgesinde oluşu ve depremlerin yıkıcı etkileri bölgenin kıyı çizgilerindeki deniz seviyesini değiştirecek ölçüde olduğunu göstermektedir. Olasılıkla 1944'te meydana gelen ve yıkıcı büyüklükte olduğu bilinen deprem sonucunda taş rıhtım hem deniz seviyesinin yükselmesi hem de taş rıhtımı oluşturan duvarların yıkılmasıyla sualtında kalmıştır.

Günümüze az sayıda ulaşan in situ bloklar ile antikçağa ait olduğu tespit edilen taş rıhtımın, büyük ticaret ya da savaş gemileri için organize edilen yüksek işçilikli limanlardan ziyade, özel amaçla inşa edilen düşük iş̧̧ilikli ve küçük kapasiteli bir rıhtım alanı olduğu anlaşılmaktadır. Aynı zamanda antik taş rıhtımın sualtında kalarak işlevini yitirmesinden sonra rıhtımın özellikle çerçeve duvarları sökülerek 1880 yııından sonraki bir tarihte aynı alana ince uzun bir iskele inşa etmek amacı ile kullanıldığı anlaşılmaktadır.

421973 yılında çekilen Orhan Aksoy'un yönetmenliğini yaptı̆̆ı, Hülya Koçyiğit - Kadir İnanır'ın oyuncu olduğu "Hayat Bayram Olsa" adlı Türk filminin 19. dakika, 47. dakika 17. saniyesi ve 49. dakika 45. saniyesinde rıhtım görülmektedir.

43 Adanın bulunduğu alandaki kıyı hattının ne denli etkilenmiş olabileceği 17 Ağustos 1999 da 7,4 şiddetinde olan İzmit depreminin yarattığı kıyı hattı değişimleri göz önüne alındığında bir çıkarım yapılabilmektedir.

44 "4 Ekim 1944'te fabrikamı faaliyete koydum. Ve yağ çıkarmaya başladık. İşten çıktıktan sonra kardeşim, Mehmet Ülgen Bey ve Enis Damar Beyle okula kadar yürüdük. Zannedersem saat 10-11 civarıydı, şimdiki Hizmet Eczanesi'nin bulunduğu meydana geldiğimizde ben bir sarsıntı hissettim. Arkadaşlarım bunu fark etmediler. Hiç birimizde bunu önemsemedik. Herkes evine gitti. O gece sabaha karşı 05.00'te çok şiddetli bir deprem oldu. Öyle ki biz kıyamet oluyor zannettik. Karşımızda bulunan eski bir eczanenin saç sundurması sarsıntıyla bütün duvarı içeri aldı ve evin terası çöktü. Karşımızdaki evlerde de hasarlar meydana geldi. Bizim evde büyük bir hasar olmadı. Ancak ön cephedeki mermer balkon kaldıraç vazifesi görerek ön üst cepheyi biraz ileriye çekti. Evimizde başka bir hasar yoktu. Ama şehirde yıkıntılar olmuştu. Sahile indiğimizde bütün rıhtım baştanbaşa yarılmış ve zifiri siyah sular ortaya çıkmıştı. Bu dönemde devlet halka çadır dağıttı. Ve biz de Enis Beylerle beraber halılarla pratik bir çadır yaparak içine yerleştik. Ama 15 Ekim gecesi yağan yağmurla yukarıdaki sokaklardan gelen sular çadırımızı istila etti. Ondan sonra sahilde bir baraka yaptık ve orada iki kış geçirdik. Ikinci kışın sonunda annemin isteğiyle evlere girdik. Adada ölüm olmadı. Yalnız ibrahim Bodin adında bir dostumuz deprem esnasında balkona çıkmış. Çok geniş olan mermer balkon aniden çökünce ibrahim de balkonla aşağıya düşmüş ama tesadüfe bakın ki mermerler çadır şeklinde düşmüş. Ve ibrahim yaralı olarak ölümden kurtuldu. Ayvalık'ın sahil yöresinde ölümler oldu (zemin sağlam olmadı̆̆ı dolgu olduğu için) çöküntülerden ölümler meydana geldi. Ama 62 yıl önce cereyan eden bu olayda kaç kişinin öldügünü hatırlamıyorum". 


\section{BIBBLIYOGRAFYA}

\section{Antik Kaynaklar}

Plin. nat.

Strab.

Vitr. de Arch.

\section{Modern Literatür}

Aka 1944

Arı 1996

Arı 2000

Aslan 2011

Aslan 2013

Bayraktar 2002

Blackman 1973

Blackman 1982

Cömert 2006

Drakos 1888

Drakos 1895

Karaiskakis 1973

Kâtip Çelebi

Kontis 1978

Neşri 1984

Pınar - Lahn 1952

Piri Reis

Psarros 2004

Ruhyan - Lewis 1985

Soysal 1981

Soysal 1983

Testaguzza 1964

Texier 1862
(= G. Plinius Secundus "Yaşı"ı", Naturalis Historia)

Kullanılan Metin ve Çeviri: Pliny, Natural History, vols. I-X. Trans. H. R. Rackham, W. H. S. Jones - D. E. Eichholz. Cambridge, Massachusetts London 1938-1971 (The Loeb Classical Library).

(= Strabon, Geographika)

Kullanılan Metin ve Çeviri: Strabo, The Geography of Strabo. Trans. H. L. Jones. London - New York 1961 (The Loeb Classical Library).

(= Vitruvius, De Architectura)

Kullanılan Metin ve Çeviriler: On Architecture, vols. I-II. Trans. F. Granger. London - New York 1931-1934 (The Loeb Classical Library).

Vitruvius, Mimarlık Üzerine On Kitap. Çev. S. Güven. İstanbul 1998.

D. Aka, Ayvalık iktisadi Coğrafyası. İstanbul 1944.

K. Arı, Kurtuluş Savaşı'nın Bitiminde Türkiye Dışına Yönelik Göçler ve Sonuçları. Ankara 1996.

K. Arı, Büyük Mübadele Türkiye’ye Zorunlu Göç (1923-1925). İstanbul 2000.

E. Aslan, Kekova Bölgesi Limanları. Yayımlanmamış Doktora Tezi, Selçuk Üniversitesi. Konya 2011.

E. Aslan, "Simena Limanı". Ed. B. Söğüt, Stratonikeia'dan Laginaya-Ahmet Adil Tırpan Armağanı. İstanbul (2013) 27-38.

B. Bayraktar, Ayvalık Tarihi. Ankara 2002.

D. J. Blackman, "Evidence of Sea Level Change in Ancient Harbours and Coastal Installations". Ed. D. J. Blackman, Marine Archaeology. Bristol (1973) 115-139.

D. J. Blackmann, "Ancient Harbours in the Mediterranean Part 1". IJNA 11/2 (1982) 79-104.

B. Cömert, Mitoloji ve ikonografi. Ankara 2006.

E. I. Drakos, Treatises on Asia Minor Area. Atina 1888.

E. I. Drakos, Küçük Asya'dan Moshonisialı'ların Tarihi. Çev. Necmi Ali (Eskidji A.S.). Atina (1895) 75-80.

S. Karaiskakis, Moshonisia i Patridamu. Çev. T. İzbek. Atina 1973.

K. Çelebi, Tuhfetü'l-Kibar Fi Esrari'l-Bihar. Haz. İ. Bostan. Ankara 2008.

D. I. Kontis, Lesbos and his Asia Minor Area. Atina 1978.

M. Neşri, Neşri Tarihi. Haz. M. A. Köymen. Ankara 1984.

N. Pınar - E. Lahn, Türkiye Depremleri İahlı Kataloğu. Ankara 1952.

Piri Reis, Kitab-ı Bahriye. Ed. E. Z. Ökte. Ankara 1988.

D. Psarros, Ayvalık/Kydonies'in Kentsel Tarihi. Egenin Iki Yakası-l. Bildiri Özetleri. Ayvalık 2004.

R. J. Ruhyan - A. R. Lewis, European Naval and Maritime History (3001500). Bloomington 1985.

H. Soysal, S. Sipahioğlu, D. Koçak, Y. Altınok, Türkiye ve Çevresinin Tarihsel Deprem Kataloğu. İstanbul 1981.

i. Soysal, Tarihçeleri ve Açıklamaları ile Birlikte Türkiye'nin Siyasal Antlaşmaları I. Ankara 1983.

O. Testaguzza, "The Port of Rome". Archaeology 17/3 (1964) 173-179.

C. Texier, L'Asie Mineure. Paris 1862. 
Theodoulou - Memos 2007

Tsernoglou 1988

Uzunçarşılı 1998

Williams 1976

Yazıcı 2003
T. Theodoulou - C. Memos, "A voyage to Ancient Greek Harbours on Board Limenoscope". Water Science \& Technology: Water Supply 7/1 (2007) 253260.

A. G. Tsernoglou, Ayvalık ve Cunda Adası'nda Kilise Bölgelerine Ait ibadethaneler ve Manastırlar. Çev. L. Alatlı. Atina 1988.

i. H. Uzunçarşılı, Osmanlı Tarihi. Cilt II. Ankara 1998.

P. F. C. Williams, "Roman Harbours". IJNA 5/1 (1976) 73-79.

N. Yazıcı, Ocak 1898 Balıkesir Depremi ve Sonrası. Ankara 2003. 